\title{
REVIEW
}

\section{Muscle atrophy in critically ill patients : a review of its cause, evaluation, and prevention}

\author{
Nobuto Nakanishi' ${ }^{1}$ Takuya Takashima ${ }^{1}$, and Jun Oto ${ }^{2}$ \\ ${ }^{1}$ Emergency and Critical Care Medicine, Tokushima University Hospital, 2-50-1 Kuramoto, Tokushima 770-8503, Japan, ${ }^{2}$ Emergency and \\ Disaster Medicine, Tokushima University Hospital, 2-50-1 Kuramoto, Tokushima 770-8503, Japan
}

\begin{abstract}
Critically ill patients exhibit prominent muscle atrophy, which occurs rapidly after ICU admission and leads to poor clinical outcomes. The extent of atrophy differs among muscles as follows: upper limb: $0.7 \%-2.4 \%$ per day, lower limb: $1.2 \%-3.0 \%$ per day, and diaphragm $1.1 \%-10.9 \%$ per day. This atrophy is caused by numerous risk factors such as inflammation, immobilization, nutrition, hyperglycemia, medication, and mechanical ventilation. Muscle atrophy should be monitored noninvasively by ultrasound at the bedside. Ultrasound can assess muscle mass in most patients, although physical assessment is limited to almost half of all critically ill patients due to impaired consciousness. Important strategies to prevent muscle atrophy are physical therapy and electrical muscular stimulation. Electrical muscular stimulation is especially effective for patients with limited physical therapy. Regarding diaphragm atrophy, mechanical ventilation should be adjusted to maintain spontaneous breathing and titrate inspiratory pressure. However, the sufficient timing and amount of nutritional intervention remain unclear. Further investigation is necessary to prevent muscle atrophy and improve long-term outcomes. J. Med. Invest. 67 : 1-10, February, 2020
\end{abstract}

Keywords : muscle atrophy, diaphragm, ultrasound, physical therapy, electrical muscular stimulation

\section{INTRODUCTION}

Mortality from critical illness has declined by $35 \%$ in the past few decades, accompanied by increased attention to functional impairments in survivors (1). One-third of patients have functional impairments following ICU discharge, which is now recognized as post-intensive care syndrome (PICS) (2). PICS encompasses impaired physical, mental, and cognitive functions (3). Even 5 years after intensive care, the patients' physical function does not return to the standard level (4), and one-third of survivors never return to work (5). Muscle weakness and atrophy acquired in the ICU are major contributors to PICS (6).

Muscle weakness in the ICU has gained increased attention as ICU-acquired weakness (ICU-AW) (7). ICU-AW is bilateral muscle weakness newly acquired in the ICU and is observed in $40-50 \%$ of critically ill patients $(8,9)$. In the ICU, prolonged bed rest and inflammation increase catabolism and microcirculatory disturbances, which cause axonal degeneration and muscle protein breakdown (9). Therefore, ICU-AW is considered to be neuropathy (critical illness polyneuropathy) or myopathy (critical illness myopathy), as well as the overlap of these two conditions (10). ICU-AW is associated with a prolonged ICU stay and high mortality (6).

Recently, many studies have investigated muscle atrophy because the diagnosis of ICU-AW is challenging $(11,12)$. Although the diagnosis of ICU-AW requires assessment of limb muscle strength, more than half of all critically ill patients cannot comply with the evaluation (13). In contrast, muscle atrophy can be evaluated for all critically ill patients. This muscle atrophy is associated with ICU-AW and encompasses the concept of ICU-AW

Received for publication June 30, 2019; accepted August 15, 2019.

Address correspondence and reprint requests to Jun Oto, MD PhD, Emergency and Disaster Medicine, Tokushima University Hospital, 2-50-1 Kuramoto, Tokushima 770-8503, Japan and Fax : +81-88-633-9339.
(14). In addition to limbs, respiratory muscle can atrophy and impede weaning from mechanical ventilation (15). Recent studies found that early mobilization and neuromuscular electrical stimulation can prevent and treat muscle atrophy in critically ill patients (16). This review focuses on the causes, evaluation, and prevention of muscle atrophy in critically ill patients.

\section{MUSCLE ATROPHY}

Noticeable reduction of muscle mass starts within 3 days of ICU stay, and progressively worsens thereafter (17). Patients with acute respiratory distress syndrome (ARDS) had a weight loss of $18 \%$ at hospital discharge, mostly due to muscle atrophy (18). Even 6 to 12 months after ICU discharge, survivors of ARDS did not regain their original muscle mass proportion, and the decreased muscle mass was associated with impaired gait speed $(\mathrm{r}=0.27-0.41, \mathrm{p}<0.05)$ and 6 -minute walk distance $(\mathrm{r}=0.36-0.42, \mathrm{p}<0.001)(19)$. The extent of muscle atrophy acquired in the ICU is different among skeletal muscles (20). Therefore, each muscle is explained separately.

\section{1-1. Lower limbs}

In our previous study, we found that the rectus femoris thickness and cross-sectional area decreased by $18.8 \%$ and $20.7 \%$, respectively, during the first 7 days (17). In other studies, the muscle mass of the rectus femoris decreased by $10.6 \%$ or 17.7 $29.9 \%$ over 7 or 10 days $(14,21,22)$. The muscle mass decreased by $29.7 \%$ in the vastus intermedius, by $14.1 \%-22.9 \%$ in the vastus lateralis, and by $11.6 \%$ in the gastrocnemius $(22,23)$ over 10 days. The mass of the tibialis anterior muscle decreased by $21 \%$ over 9 days (24). Thus, the atrophy rate in lower limbs is $1.2 \%-3.0 \%$ per day $(17,21-23)$. Similarly, in pediatric patients, the thickness of the quadriceps femoris muscle decreased by $1.5 \%$ per day (25). The decreased quadriceps cross-sectional area during the ICU stay further decreased 7 days after ICU discharge, and the muscle atrophy remained in $73 \%$ of patients with 
impaired physical function 6 months after ICU discharge (26).

\section{1-2. Upper limbs}

Muscle atrophy in upper limbs is controversial. In our previous study, the thickness and cross-sectional area of the biceps brachii muscle decreased by $13.2 \%$ and $16.9 \%$, respectively, over the 7 days of ICU admission (17). Similarly, in septic patients, the muscle thickness decreased by $7.6 \%$ over the 7 days (14). On the other hand, Turton et al. found that the muscle thickness of the upper limbs in ICU patients did not decrease significantly from ICU admission to the 10 th day $(3.20 \pm 0.58 \mathrm{~cm}$ to $2.98 \pm 0.83 \mathrm{~cm}$, $\mathrm{p}=0.62$ ), although the lower limb muscle mass significantly decreased (23). In another study, the muscle thickness of the upper limbs did not change in bed-ridden healthy volunteers (27). The differences may be explained by the severity of illness or patient's consciousness because less critical patients can use their arms during bed rest, and such activation of biceps brachii muscles may have counteracted the atrophy. Similarly, in critically ill pediatric patients, biceps muscle atrophy did not significantly change $(-1.71 \% ; 95 \% \mathrm{CI},-8.15 \%$ to $4.73 \% ; \mathrm{p}=0.59)$ over the 6 days (25). In conclusion, the atrophy rate of the upper limbs is lower than that of the lower limbs, at $0.7 \%-2.4 \%$ per day in critically ill patients $(14,17,23)$.

\section{1-3. Pectoralis major muscle}

The pectoralis major muscle is important in critically ill patients because a larger pectoralis major muscle was related to a higher 6 -month survival rate (odds ratio [OR], 1.03 ; 95\% CI, $1.01-1.04 ; \mathrm{P}<.001)(28)$. Over the 5 days of ICU admission, the atrophy of the pectoralis major muscle was limited to only $29 \%$ of patients, and the change in thickness was not significant (5.6 $\mathrm{mm}$ [4.8-6.9] to $5.9 \mathrm{~mm}$ [4.9-7.0], $\mathrm{p}=0.308$ ) (29). Similarly, Levine et al. found that the muscle fibers of the pectoralis major muscle did not differ between mechanically ventilated patients and control subjects, although the study only compared 22 patients with different pathologies (30). Further investigation is needed to conclude the rate of atrophy of the pectoralis major muscle.

\section{1-4.Diaphragm}

Patients undergoing prolonged mechanical ventilation have sustained diaphragm muscle loss, which leads to poorer clinical outcomes (15). Diaphragm muscle atrophy occurs in $41-44 \%$ of patients according to previous studies $(15,31)$. Diaphragm muscle atrophy is separated from limb muscle atrophy because it is constantly activated by mechanical ventilation, whereas the limb muscles are not constantly active. Thus, in a previous study, the correlation between diaphragm dysfunction and limb muscle weakness was weak ( $r=0.26-0.28, p \leq 0.03)$, and only $21 \%$ of patients had both diaphragm and limb muscle weakness (20). In another study, diaphragm atrophy was more prominent than psoas muscle atrophy at 25 days after the first measurement (diaphragm vs. psoas : $-27 \% \pm 12 \%$ vs. $-19 \% \pm 13 \%$ ) (32). The atrophy rate of the diaphragm is $2.4 \%-10.9 \%$ per day during mechanical ventilation $(31,33,34)$ and $1.1 \%-2.4 \%$ per day during ICU stay $(29,32)$. In pediatric patients, the diaphragm atrophy rate was $3.4 \%$ per day during mechanical ventilation (35).

Of note, the diaphragm exhibits not only atrophy, but also hypertrophy (36). Hypertrophy occurs in $12 \%-24 \%$ of mechanically ventilated patients $(15,31)$. In patients with diaphragm hypertrophy, the diaphragm thickness increased by approximately $17 \%$ over the 8 days of mechanical ventilation. The diaphragm muscle can be thickened by insufficient ventilatory support and excessive inspiratory load because this condition functions as resistance training of the diaphragm muscle (34). As such, diaphragm hypertrophy is associated with prolonged mechanical ventilation (OR, 1.38 ; 95\% CI, 1.00-1.90) (15). However, the clinical implications of diaphragm hypertrophy require further investigation because few studies have been reported $(15,34)$.

\section{1-5 Other respiratory muscles}

In addition to the diaphragm, other respiratory muscles play an important role in moving the rib cage in patients with acute respiratory failure who have difficulty breathing (37). Among other respiratory muscles, the intercostal muscles exhibited atrophy in rabbits (38). In the study, the intercostal muscle mass decreased by $29 \%$ over the 48 hours of mechanical ventilation. In chronic obstructive pulmonary disease (COPD), the intercostal muscle can atrophy due to progression of the disease (39). However, the atrophy of intercostal muscles and other accessary respiratory muscles, including the sternocleidomastoid and rectus abdominis muscles, is unclear in critically ill patients.

\section{RISK FACTORS}

\section{2-1. Inflammation}

Inflammation is the main cause of muscle atrophy in the early course of critical illness (Fig. 1) (40). In patients who develop ICU-AW, the level of inflammatory cytokines, including interleukin 6,8 , and 10 , was significantly higher (OR, 1.35 ; 95\% CI, 1.18-1.55) in the first 4 days after ICU admission (41). Intramuscular inflammation causes catabolism and impairs anabolic signaling with consequent muscle mass reduction $(42,43)$. Sepsis accompanies systemic inflammation, and leads to upper and lower limb muscle atrophy (14). Moreover, multiple organ failure, which is often the consequence of inflammation, leads to prominent muscle atrophy (21).

\section{2-2. Immobilization}

Critically ill patients are often immobilized due to the severity of illness and equipment such as mechanical ventilation (44). This immobilization leads to muscle atrophy (45). Even in healthy volunteers, the bed-ridden state causes the lower limb muscles to atrophy by $0.2 \%-0.6 \%$ per day $(27,46)$. However, patients in the ICU exhibit more prominent muscle atrophy at $1.2 \%-3.0 \%$ per day due to multiple causes (45).

\section{2-3. Nutrition}

Although catabolism plays a greater role in muscle atrophy than impaired synthesis (47), malnutrition is also an important cause of muscle atrophy (45). The nutrition of critically ill patients is often delayed or interrupted (48). Moreover, patients in the ICU frequently have problems absorbing the nutrition due to the enteral intolerance (49).

\section{2-4. Hyperglycemia}

Hyperglycemia is often a consequence of inflammation, but it is identified as an independent risk factor for muscle atrophy because it impairs mitochondrial function (50) and promotes the muscle atrophy pathway (51). Moreover, hyperglycemia secondarily causes ischemia of muscles and nerves (10), and is associated with ICU-AW (OR, 2.86 ; 95\% CI, 1.30-6.30; $p=0.009)(52)$.

\section{2-5. Medication}

Neuromuscular-blocking agents are often used for ARDS as a lung-protective strategy. However, their effects on muscle and physical function are unclear. In a recent study of ARDS, neuromuscular-blocking agents lead to a higher incidence of ICU-AW, although not significantly (47.3\% in intervention vs. $39.0 \%$ in the control) (13). In a meta-analysis of a general ICU population, neuromuscular-blocking agent usage was associated with the 


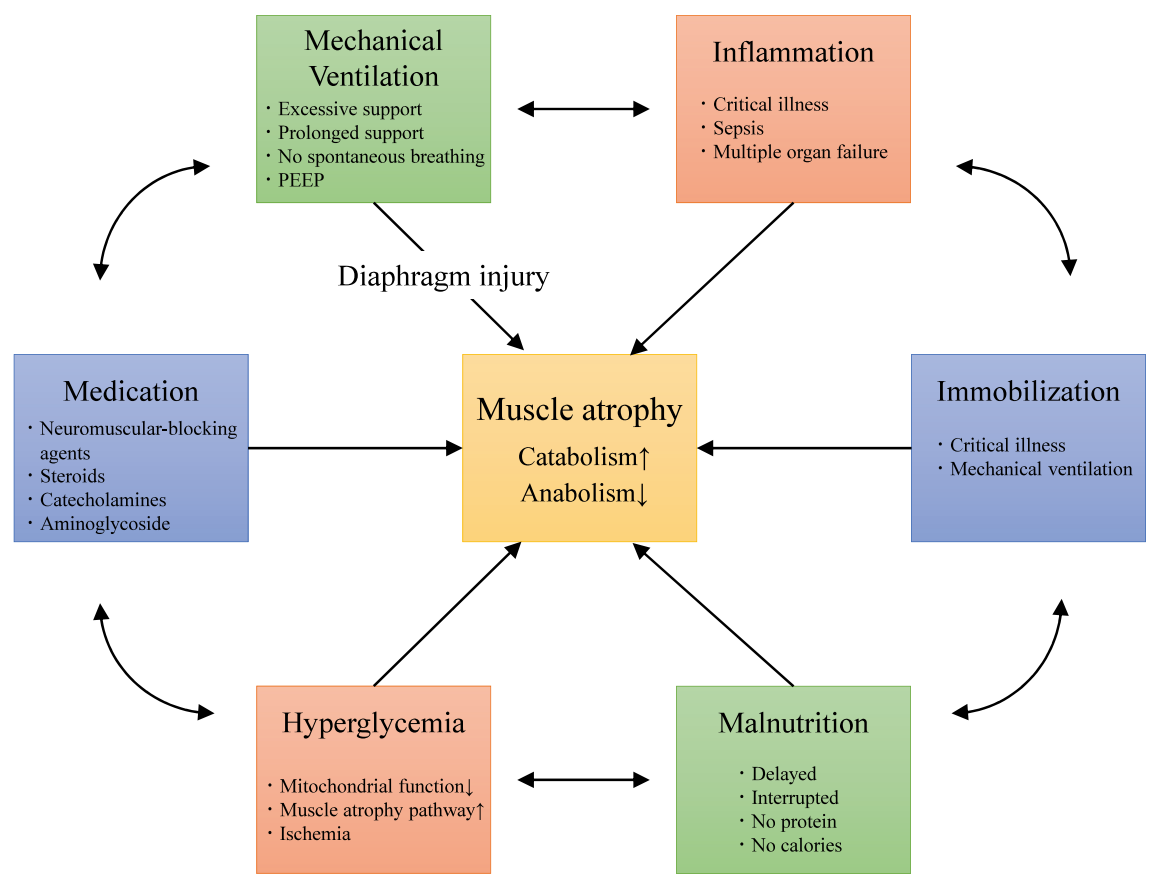

Figure 1. Risk factors associated with muscle atrophy

Critically ill patients are exposed to numerous risk factors for muscle atrophy. PEEP, positive end-expiratory pressure

risk of ICU-AW (OR, $2.03 ; 95 \%$ CI, 1.22-3.40) (53). For the diaphragm, neuromuscular-blocking agents caused significant muscle atrophy $(-16.4 \%$ [IQR, $-28.4 \%$ to $-7.0 \%]$ for neuromuscular-blocking agents vs. $-7.3 \%$ [IQR, $-10.9 \%$ to $0 \%]$ for control, $\mathrm{p}=0.036)(35)$

Steroids are frequently used in the ICU, but they should be used carefully because they inhibit protein synthesis and activate protein degradation (54). Indeed, steroid use is associated with pectoral muscle atrophy (Atrophy ratio : $58 \%$ in patients treated by steroids vs. $14 \%$ in the control, $p=0.006$ ) (28) and ICU-AW (OR, $1.84 ; 95 \%$ CI, 1.26-2.67) (55). The combined use of steroids and neuromuscular-blocking agents is more deleterious to muscle than steroids alone (56).

Catecholamines can maintain organ perfusion in shock. Although arrhythmias and ischemia are well-known side effects, a recent study found that catecholamines are associated with ICUAW (OR, 3.20 ; 95\% CI, 1.29-7.95) (55). During the use of catecholamines, the stimulation of $\beta$-adrenergic receptors has toxic effects on skeletal muscle, as reported in animal studies $(57,58)$.

Aminoglycoside is a widely used wide-spectrum antibiotic. Among its side effects, it is toxic to peripheral neurons and has well-known ototoxicity (59). The use of aminoglycoside increased the incidence of ICU-AW (OR, 2.27 ; 95\% CI, 1.07-4.81; $\mathrm{p}<0.05)$ (53).

\section{2-6. Mechanical ventilation}

Mechanical ventilation is associated with diaphragm atrophy (30). Diaphragm atrophy progresses rapidly after mechanical ventilation and prolonged mechanical ventilation is a risk factor for prominent atrophy (31). The extent of atrophy differs among ventilator settings. Excessive ventilatory support causes diaphragm atrophy (60). Based on diaphragm biopsy, the patient group without spontaneous breathing presented significant diaphragm atrophy (61). Positive end-expiratory pressure (PEEP) also resulted in diaphragm atrophy by excessive stretching of muscle fibers (62). These structural changes of the diaphragm are termed myotrauma, and recognized as a serious complication of mechanical ventilation (63).

\section{EVALUATION AND DIAGNOSIS}

\section{3-1. Physical assessment}

Physical assessment is useful to evaluate muscle weakness. For ICU-AW, the medical research council (MRC) score is used for diagnosis (64). The MRC score is based on the manual testing of 6 muscle groups on both sides (0-60 score) (12). ICU-AW is defined as an MRC score of less than 48 without preexisting neuromuscular problems (64). As physical assessments require the patient's cooperation, the assessment of ICU-AW was incomplete for $53.9 \%$ of mechanically ventilated patients and $51.2 \%-67.5 \%$ of acute respiratory distress syndrome (ARDS) patients (13, 65). Moreover, some patients have impaired muscle strength at admission (66).

\section{3-2. Ultrasound}

Ultrasound is the most commonly used method for monitoring of muscle mass because it is noninvasively available at the bedside (67). In contrast to assessment by MRC score, ultrasound can assess muscle atrophy for all critically ill patients regardless of their consciousness level and preadmission status. The measurement is conducted using a linear transducer and generous amounts of gel to avoid compression of the muscles (67). However, the measurement site is not consistent among studies. The most common site of muscle mass measurement is the rectus femoris muscle. Its measurement is reproducible $\left(\mathrm{R}^{2}=0.74-0.99\right)(17$, 21,68 ) and needs only minimal training $(69)$. The measurement site is midway or one-third from the proximal patella to the anterior superior iliac spine or $10 \mathrm{~cm}$ above the proximal patella $(17,21,67,70)$. Measurement by ultrasound should be conducted using the cross-sectional area (Fig. 2ab) rather than thickness because muscle thickness is inaccurate (71). Moreover, the 
a

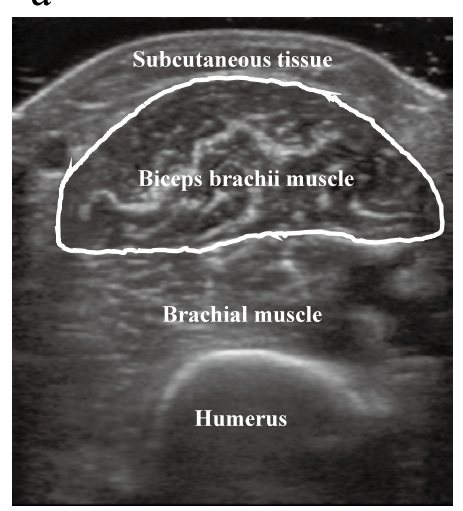

b

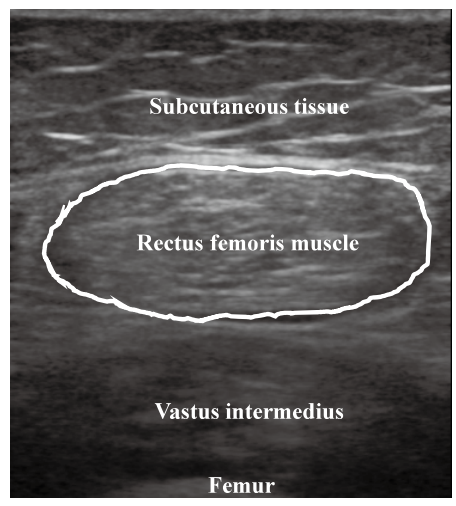

c

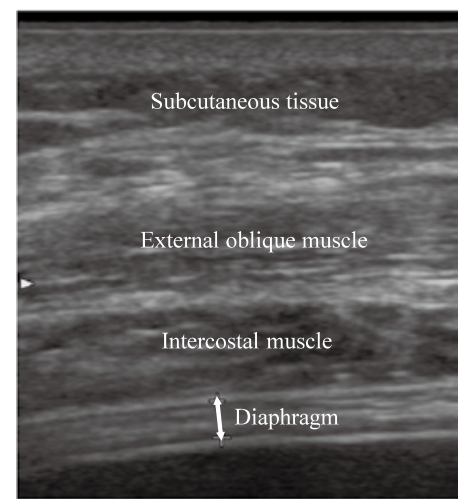

Figure 2. Typical ultrasonographic images of upper limbs, lower limbs, and diaphragm a. Cross-sectional area of the biceps brachii muscle in the transverse plane. b. Cross-sectional area of the rectus femoris muscle in the transverse plane. c. Diaphragm thickness from the right intercostal view.

cross-sectional area reflects the muscle strength (72). Although edema was reported to influence ultrasonographic assessment, it is not significant because most fluid is not retained in muscle and is instead in subcutaneous tissues $(73,74)$. The diaphragm thickness is evaluated by a perpendicularly placed transducer at $0.5-2 \mathrm{~cm}$ below the right costophrenic sinus, which is termed the zone of apposition (Fig. 2c) (75). The muscle echo intensity is useful for assessing muscle atrophy because it increases in atrophied muscle (22). This high intensity reflects the increased percentage of interstitial fibrous tissue (76).

\section{3-3. BIA (Bioelectrical impedance analysis)}

BIA can be used at the bedside (Fig. 3). BIA indirectly measures whole-body muscle mass from the impedance using a weak electric current. The muscle mass, measured by BIA, correlates well with the CT assessment in critically ill patients (77). However, edema complicates the impedance and muscle mass measurement, and muscle mass was thus overestimated in edematous patients (77). Muscle mass monitoring during ICU stay may be unreliable because critical ill patients exhibit an abnormal fluid status (78).

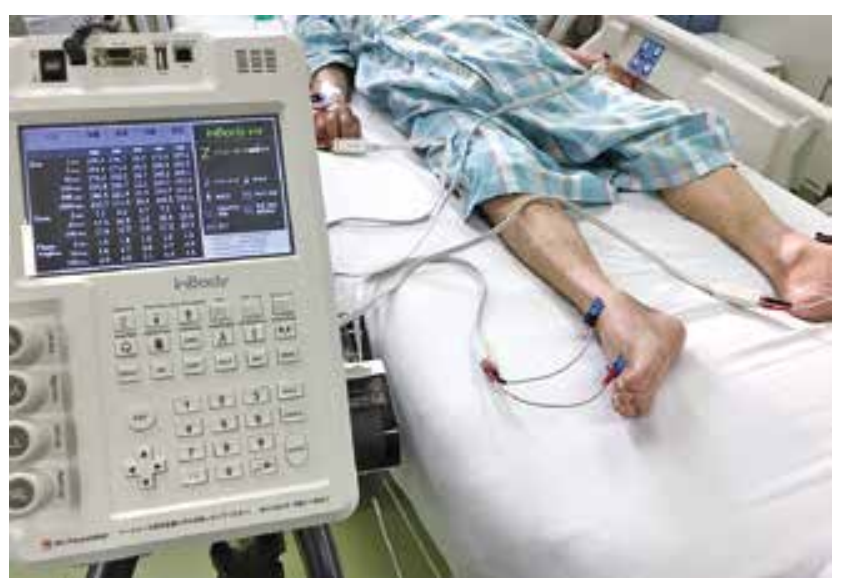

Figure 3. Bioelectrical impedance analysis

The whole-body muscle mass was measured by bioelectrical impedance analysis (InBody S10 ${ }^{\circledR}$, InBody Co., Seoul, South Korea). Patient consent was obtained for the use of this image.

\section{3-4.CT, MRI, and DEXA}

Computed tomography (CT), magnetic resonance imaging (MRI), and dual energy x-ray absorptiometry (DEXA) are reliable methods of muscle mass assessment but are unavailable at the bedside (79). Furthermore, CT and X-ray expose patients to extra radiation, and transferring patients to the examination room involves some risks. Therefore, these methods are not suitable for muscle mass monitoring in critically ill patients.

\section{3-5. Biomarkers}

Creatine kinase is normal or mildly high in ICU-AW, but it is not a specific biomarker $(64,65)$. Growth and differentiation factor-15 (GDF-15) is considered to be a mediator of muscle atrophy, and the level of GDF-15 increased in the muscle atrophy group (80). Furthermore, the GDF-15 level in plasma was higher in ICU-AW (7239 pg/mL vs. $2454 \mathrm{pg} / \mathrm{mL}, \mathrm{p}=0.001)(81)$. Therefore, the measurement of GDF-15 is promising for the diagnosis of muscle atrophy. In a recent study, the serum creatinine to serum cystatin $\mathrm{C}$ ratio was reported to correlate with muscle mass $(r=0.62, p<0.001)(82)$, but it is limited to patients without acute kidney injury. Under normal renal function, urinary creatinine and 3-methylhistidine are also useful for monitoring proteolysis and evaluating muscle atrophy $(83,84)$.

\section{PREVENTION AND TREATMENTS}

As inflammation is the main cause of muscle atrophy in the early course of critical illness, treating the causative disease should be prioritized. As additional interventions, rehabilitation and nutritional support are indispensable for preventing muscle atrophy (Table 1).

\section{4-1. Physical therapy}

Early mobilization has been demonstrated to be an effective method to prevent physical disabilities (85) and improve longterm outcomes (86). Early physical therapy prevented muscle atrophy by preserving the muscle fiber cross-sectional area at day 7 of ICU admission $(2.4 \% \pm 22.5 \%$ in the intervention group vs. $-25.8 \% \pm 21.6 \%$ in the control, $p=0.005)(11)$. Moreover, early mobilization was confirmed to be effective in preventing ICU-AW (87). Physical therapy for respiratory muscles can improve both inspiratory and expiratory muscle strength (88). 
Table 1. Strategies to prevent muscle atrophy in critically ill patients.

Summary of strategies aimed at preventing muscle atrophy in critically ill patients.

Recommendation was determined by the level of evidence. Recommended: based on meta-analysis, systematic review, or randomized controlled trial. Moderately recommended: based on observational study. *The effects of electrical muscular stimulation may vary in the included study population.

\begin{tabular}{lll}
\hline Interventions & Prevention of muscle atrophy & Evidence \\
\hline Limbs & & \\
Physical therapy & Recommended & $(11),(85)$ \\
Electrical muscular stimulation & Recommended with limitation* & $(12),(90),(92),(93)$ \\
Nutrition (timing, protein, calories) & Unknown & $(101),(109)$ \\
Diaphragm & & \\
Inspiratory muscle training & Recommended for muscle strength & $(88)$ \\
Electrical diaphragm muscle stimulation & No clinical data & $(96),(97)$ \\
Maintaining spontaneous breathing & Moderately recommended & $(60),(61)$ \\
Titrating inspiratory pressure & Moderately recommended & $(60)$ \\
Titrating PEEP & No clinical data & $(62)$ \\
\hline
\end{tabular}

\section{4-2.EMS (Electrical muscular stimulation)}

EMS uses electrical currents to induce muscle construction, and can be used safely as additional rehabilitation for ICU patients (Fig. 4) (89). EMS aided in preserving muscle mass in critically ill patients over the 7 or 8 days of ICU stay (cross-sectional area of the rectus femoris muscle ; $-8 \% \pm 3.9 \%$ in the EMS group vs. $-13.9 \% \pm 6.4 \%$ in the control, $\mathrm{p}<0.05)(90)$. In contrast, a recent study reported adding EMS to the lower legs did not preserve muscle mass at the day of ICU discharge (thickness of the rectus femoris ; $-1.9 \mathrm{~mm}[-8.0$ to $0.2 \mathrm{~mm}]$ in the intervention group vs. $-2.4 \mathrm{~mm}[-7.1$ to $-0.3 \mathrm{~mm}]$ in the control, $\mathrm{p}=0.17)(91)$. In this randomized controlled trial, early physical therapy was conducted for both groups (the control group had early standardized rehabilitation). Patients who have sufficient physical therapy may benefit little from EMS, but it may be useful for patients with limited mobility because active patient cooperation is not required. Which patients will benefit the most from these additional rehabilitation methods needs to be clarified. In previous studies, EMS was effective for patients requiring a prolonged ICU stay (92) or prolonged mechanical ventilation (12). EMS preserved muscle thickness of the rectus femoris only in patients requiring long-term ICU stay (4.9\% in the intervention

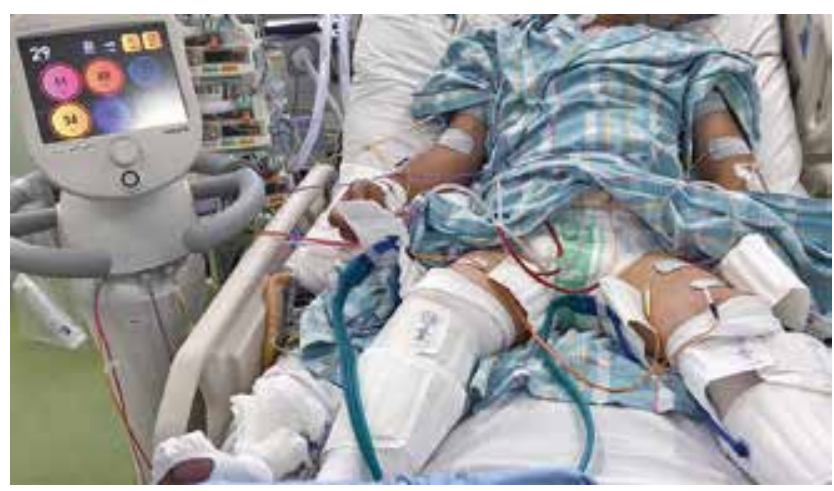

Figure 4. Electrical muscular stimulation in a critically ill patient Bilateral upper and lower limbs were stimulated by electrical muscular stimulation (Solius, Minato Medical Science Co., Osaka, Japan). Patient consent was obtained for the use of this image. group vs. $-3.2 \%$ in the control, $p=0.013$ ). Similarly, in patients under prolonged mechanical ventilation, the leg circumference was preserved $(47.5 \pm 8.3 \mathrm{~cm}$ in the intervention group vs. $44.6 \pm 5.7 \mathrm{~cm}$ in the control, $\mathrm{p}=0.004)(12)$. One previous study evaluated the effects of EMS on one side of the upper limbs, and the non-stimulated arm circumference decreased significantly over 13 days $(-1.00 \mathrm{~cm}$ [IQR, -2.50 to $0.00 \mathrm{~cm}], \mathrm{p}=0.015)(93)$. However, the recommendation of EMS for critically ill patients is not consistent in the guidelines due to the limited number of studies $(94,95)$.

EMS to the diaphragm through the phrenic nerve has been investigated in an animal study, and it was effective in preventing diaphragm muscle atrophy (diaphragm thickness/ initial value; 1.10 [IQR, 1.02-1.24] in the intervention group vs. 0.84 [IQR, 0.78-0.89] in the control, $p=0.001)(96)$. Its application in humans is currently under investigation (97).

\section{4-3 Ventilator settings}

Ventilator settings preventing diaphragm muscle atrophy are termed "muscle-protective ventilation" (98). This strategy aims at maintaining spontaneous breathing and titrating ventilatory support to obtain sufficient respiratory effort, but some patients with ARDS need ventilator settings without spontaneous breathing to avoid ventilator-induced lung injury (99). However, the setting without spontaneous breathing should be carefully used because this mode leads to prominent diaphragm atrophy of $-7.5 \% \pm 12.3 \%$ per day (60). Similarly, excessive respiratory support should be avoided because higher inspiratory pressure leads to further diaphragm atrophy (daily atrophy ratio $;-5.6 \% \pm 12.9 \%$ in $\geq 12 \mathrm{cmH}_{2} \mathrm{O}$ vs. $-1.5 \% \pm 10.9 \%$ in $5-12$ $\mathrm{cmH}_{2} \mathrm{O}$ ) (60). The optimal ventilator settings can be adjusted by ultrasonographic measurement of the diaphragm thickening fraction [thickness at inspiration - thickness at expiration]/ [thickness at expiration] $\times 100$ (\%) (34). The diaphragm thickening fraction represents the respiratory effort by the patient (100). For better clinical outcomes, the thickening fraction should be maintained from $15 \%$ to $30 \%$, which is the same range during spontaneous breathing in healthy adults (15).

\section{4-4 Nutrition \\ 4-4-1 Early enteral and parenteral nutrition}

Early enteral or parenteral nutrition is not promising for phys- 
ical function. In a previous study, early and full enteral nutrition during the first 6 days did not change physical function 6 and 12 months after ICU discharge (101). Similarly, early parenteral nutrition, compared with late parenteral nutrition beyond the first week, did not prevent muscle atrophy and only increased adipose tissue (102). Moreover, early parenteral nutrition was associated with ICU-AW ( $p=0.021)(103)$, mainly due to unutilized nutrition in the acute phase of critical illness (104). Indeed, $63 \%$ of early intake is excreted (105). Hyperglycemia and dyslipidemia, which are common complications of early nutrition, are harmful to muscles and nerves (106).

\section{4-4-2 Protein}

Protein intake from $1.2-1.5$ or $1.2-2.0 \mathrm{~g} / \mathrm{kg} /$ day is recommended for lower mortality $(107,108)$. However, the necessary amount of protein to prevent muscle atrophy is unclear. In a randomized controlled trial of non-septic critically ill patients, protein intake was decided by nitrogen balance (difference between given amount and urinary excretion), and the actual protein intake was $1.47 \mathrm{~g} / \mathrm{kg} /$ day in the intervention group vs. $0.50 \mathrm{~g} / \mathrm{kg} / \mathrm{day}$ in the control. However, the higher protein intake did not change the physical quality of life at 6 months (109). In another study on septic patients, a higher protein intake was associated with prominent muscle atrophy (OR, 1.29; 95\% CI, $1.00-1.67 ; \mathrm{P}<0.049)$, possibly due to the deteriorated autophagy activity in septic patients $(21,110)$. In contrast, a higher protein intake was reported to increase the forearm muscle thickness on ultrasound ( $3.2 \pm 0.4 \mathrm{~cm}$ vs. $2.8 \pm 0.4 \mathrm{~cm}, \mathrm{p}<0.0001)$, although the actual difference in protein intake was small $(0.9 \mathrm{~g} / \mathrm{kg}$ vs. 1.1 $\mathrm{g} / \mathrm{kg}$ ) (111). Results regarding the necessary amount of protein to prevent muscle atrophy are conflicting. The existence of negative data suggests that nutritional intervention alone is insufficient to prevent muscle atrophy, and that it should be combined with physical therapy.

\section{4-4-3 Calories}

In recent years, permissive underfeeding is recommended in the first week of critical illness $(107,109)$. In an observational study, low caloric intake on day $3(<10 \mathrm{kcal} / \mathrm{kg} /$ day $)$ was associated with good physical status at ICU discharge (112). In another study, calorimetry-based full calorie intervention did not change the physical quality of life at 6 months $(1877 \mathrm{kcal} /$ day in the intervention group vs. $1061 \mathrm{kcal} /$ day in the control) (109). The benefits of permissive underfeeding are being investigated in many trials.

\section{4-5 Glucose control}

Intensive insulin therapy (blood glucose levels of 80 to $110 \mathrm{mg} /$ dl) reduced the incidence of ICU-AW (50.5\% in the intervention group vs. $38.9 \%$ in the control, $p=0.02$ ) (113). In addition to the benefits of preventing abnormal glucose levels, insulin can promote muscle anabolism (114).

\section{CONCLUSIONS}

Progressive muscle atrophy occurs in critically ill patients because they are exposed to numerous risk factors. As muscle atrophy leads to poor clinical outcomes, muscle mass should be monitored by ultrasound because of its noninvasiveness and demonstrated utility. For prevention, rehabilitation and EMS will help preserve muscle mass, and their combination with nutritional management is promising. Further investigation is necessary to prevent muscle atrophy and improve long-term outcomes.

\section{CONFLICTS OF INTEREST}

The authors declare no conflicts of interest.

\section{REFERENCES}

1. Zimmerman JE, Kramer AA, Knaus WA: Changes in hospital mortality for United States intensive care unit admissions from 1988 to 2012. Crit Care 17 : R81, 2013

2. Yende S, Austin S, Rhodes A, Finfer S, Opal S, Thompson T, Bozza FA, LaRosa SP, Ranieri VM, Angus DC : Long-term quality of life among survivors of severe sepsis : analyses of two international trials. Crit Care Med 44 : 1461-1467, 2016

3. Ohtake PJ, Lee AC, Scott JC, Hinman RS, Ali NA, Hinkson CR, Needham DM, Shutter L, Smith-Gabai H, Spires MC, Thiele A, Wiencek C, Smith JM : Physical impairments associated with post-intensive care syndrome : systematic review based on the World Health Organization's international classification of functioning, disability and health framework. Phys Ther 98:631-645, 2018

4. Herridge MS, Tansey CM, Matte A, Tomlinson G, DiazGranados N, Cooper A, Guest CB, Mazer CD, Mehta S, Stewart TE, Kudlow P, Cook D, Slutsky AS, Cheung AM : Functional disability 5 years after acute respiratory distress syndrome. N Engl J Med 364 : 1293-1304, 2011

5. Kamdar BB, Sepulveda KA, Chong A, Lord RK, Dinglas VD, Mendez-Tellez PA, Shanholtz C, Colantuoni E, von Wachter TM, Pronovost PJ, Needham DM : Return to work and lost earnings after acute respiratory distress syndrome : a 5-year prospective, longitudinal study of longterm survivors. Thorax $73: 125-133,2018$

6. Ali NA, O’Brien JM, Jr., Hoffmann SP, Phillips G, Garland A, Finley JC, Almoosa K, Hejal R, Wolf KM, Lemeshow S, Connors AF, Jr., Marsh CB : Acquired weakness, handgrip strength, and mortality in critically ill patients. Am J Respir Crit Care Med 178 : 261-268, 2008

7. Hermans G, Van den Berghe G : Clinical review : intensive care unit acquired weakness. Crit Care $19: 274,2015$

8. Appleton RT, Kinsella J, Quasim T: The incidence of intensive care unit-acquired weakness syndromes: a systematic review. J Intensive Care Soc 16 : 126-136, 2015

9. Stevens RD, Dowdy DW, Michaels RK, Mendez-Tellez PA, Pronovost PJ, Needham DM : Neuromuscular dysfunction acquired in critical illness : a systematic review. Intensive Care Med 33: 1876-1891, 2007

10. Kress JP, Hall JB : ICU-acquired weakness and recovery from critical illness. N Engl J Med 370 : 1626-1635, 2014

11. Hickmann CE, Castanares-Zapatero D, Deldicque L, Van den Bergh P, Caty G, Robert A, Roeseler J, Francaux M, Laterre PF : Impact of very early physical therapy during septic shock on skeletal muscle: a randomized controlled trial. Crit Care Med 46 : 1436-1443, 2018

12. Chen YH, Hsiao HF, Li LF, Chen NH, Huang CC : Effects of electrical muscle stimulation in subjects undergoing prolonged mechanical ventilation. Respir Care 64 : 262-271, 2019

13. Moss M, Huang DT, Brower RG, Ferguson ND, Ginde AA, Gong MN, Grissom CK, Gundel S, Hayden D, Hite RD, Hou PC, Hough CL, Iwashyna TJ, Khan A, Liu KD, Talmor D, Thompson BT, Ulysse CA, Yealy DM, Angus DC : Early neuromuscular blockade in the acute respiratory distress syndrome. N Engl J Med 380 : 1997-2008, 2019

14. Hadda V, Kumar R, Khilnani GC, Kalaivani M, Madan K, Tiwari P, Mittal S, Mohan A, Bhalla AS, Guleria R : Trends of loss of peripheral muscle thickness on ultrasonography 
and its relationship with outcomes among patients with sepsis. J Intensive Care $6: 81,2018$

15. Goligher EC, Dres M, Fan E, Rubenfeld GD, Scales DC, Herridge MS, Vorona S, Sklar MC, Rittayamai N, Lanys A, Murray A, Brace D, Urrea C, Reid WD, Tomlinson G, Slutsky AS, Kavanagh BP, Brochard LJ, Ferguson ND : Mechanical ventilation-induced diaphragm atrophy strongly impacts clinical outcomes. Am J Respir Crit Care Med $197:$ 204-213, 2018

16. Trethewey SP, Brown N, Gao F, Turner AM : Interventions for the management and prevention of sarcopenia in the critically ill : a systematic review. J Crit Care $50: 287-295$, 2019

17. Nakanishi N, Oto J, Tsutsumi R, Iuchi M, Onodera M, Nishimura M : Upper and lower limb muscle atrophy in critically ill patients : an observational ultrasonography study. Intensive Care Med 44 : 263-264, 2018

18. Herridge MS, Cheung AM, Tansey CM, Matte-Martyn A, Diaz-Granados N, Al-Saidi F, Cooper AB, Guest CB, Mazer CD, Mehta S, Stewart TE, Barr A, Cook D, Slutsky AS : One-year outcomes in survivors of the acute respiratory distress syndrome. N Engl J Med 348 : 683-693, 2003

19. Chan KS, Mourtzakis M, Aronson Friedman L, Dinglas VD, Hough CL, Ely EW, Morris PE, Hopkins RO, Needham $\mathrm{DM}$ : Evaluating muscle mass in survivors of acute respiratory distress syndrome: a 1-year multicenter longitudinal study. Crit Care Med 46 : 1238-1246, 2018

20. Dres M, Dube BP, Mayaux J, Delemazure J, Reuter D, Brochard L, Similowski T, Demoule A : Coexistence and impact of limb muscle and diaphragm weakness at time of liberation from mechanical ventilation in medical intensive care unit patients. Am J Respir Crit Care Med 195 : 57-66, 2017

21. Puthucheary ZA, Rawal J, McPhail M, Connolly B, Ratnayake G, Chan P, Hopkinson NS, Phadke R, Dew T, Sidhu PS, Velloso C, Seymour J, Agley CC, Selby A, Limb M, Edwards LM, Smith K, Rowlerson A, Rennie MJ, Moxham J, Harridge SD, Hart N, Montgomery HE : Acute skeletal muscle wasting in critical illness. JAMA $310: 1591-1600,2013$

22. Parry SM, El-Ansary D, Cartwright MS, Sarwal A, Berney S, Koopman R, Annoni R, Puthucheary Z, Gordon IR, Morris $\mathrm{PE}$, Denehy L: Ultrasonography in the intensive care setting can be used to detect changes in the quality and quantity of muscle and is related to muscle strength and function. J Crit Care 30 : 1151.e1159-1114, 2015

23. Turton P, Hay R, Taylor J, McPhee J, Welters I : Human limb skeletal muscle wasting and architectural remodeling during five to ten days intubation and ventilation in critical care - an observational study using ultrasound. BMC Anesthesiol $16: 119,2016$

24. Llano-Diez M, Renaud G, Andersson M, Marrero HG, Cacciani N, Engquist H, Corpeno R, Artemenko K, Bergquist J, Larsson L : Mechanisms underlying ICU muscle wasting and effects of passive mechanical loading. Crit Care 16 : R209, 2012

25. Johnson RW, Ng KWP, Dietz AR, Hartman ME, Baty JD, Hasan N, Zaidman CM, Shoykhet M : Muscle atrophy in mechanically-ventilated critically ill children. PLoS One 13 : e0207720, 2018

26. Dos Santos C, Hussain SN, Mathur S, Picard M, Herridge M, Correa J, Bain A, Guo Y, Advani A, Advani SL, Tomlinson G, Katzberg H, Streutker CJ, Cameron JI, Schols A, Gosker HR, Batt J : Mechanisms of chronic muscle wasting and dysfunction after an intensive care unit stay. a pilot study. Am J Respir Crit Care Med 194 : 821830,2016
27. de Boer MD, Seynnes OR, di Prampero PE, Pisot R, Mekjavic IB, Biolo G, Narici MV : Effect of 5 weeks horizontal bed rest on human muscle thickness and architecture of weight bearing and non-weight bearing muscles. Eur J Appl Physiol 104: 401-407, 2008

28. Jaitovich A, Khan M, Itty R, Chieng HC, Dumas CL, Nadendla P, Fantauzzi JP, Yucel RM, Feustel PJ, Judson MA : ICU admission muscle and fat mass, survival, and disability at discharge: a prospective cohort study. Chest 155 : 322-330, 2019

29. Vivier E, Roussey A, Doroszewski F, Rosselli S, Pommier C, Carteaux G, Mekontso Dessap A : Atrophy of diaphragm and pectoral muscles in critically ill patients. Anesthesiology, 2019

30. Levine S, Nguyen T, Taylor N, Friscia ME, Budak MT, Rothenberg P, Zhu J, Sachdeva R, Sonnad S, Kaiser LR, Rubinstein NA, Powers SK, Shrager JB : Rapid disuse atrophy of diaphragm fibers in mechanically ventilated humans. N Engl J Med 358 : 1327-1335, 2008

31. Schepens T, Verbrugghe W, Dams K, Corthouts B, Parizel PM, Jorens PG: The course of diaphragm atrophy in ventilated patients assessed with ultrasound : a longitudinal cohort study. Crit Care $19: 422,2015$

32. Jung B, Nougaret S, Conseil M, Coisel Y, Futier E, Chanques G, Molinari N, Lacampagne A, Matecki S, Jaber S : Sepsis is associated with a preferential diaphragmatic atrophy: a critically ill patient study using tridimensional computed tomography. Anesthesiology 120 : 1182-1191, 2014

33. Grosu HB, Lee YI, Lee J, Eden E, Eikermann M, Rose $\mathrm{KM}$ : Diaphragm muscle thinning in patients who are mechanically ventilated. Chest $142: 1455-1460,2012$

34. Goligher EC, Fan E, Herridge MS, Murray A, Vorona S, Brace D, Rittayamai N, Lanys A, Tomlinson G, Singh JM, Bolz SS, Rubenfeld GD, Kavanagh BP, Brochard LJ, Ferguson ND : Evolution of diaphragm thickness during mechanical ventilation. Impact of inspiratory effort. Am J Respir Crit Care Med 192 : 1080-1088, 2015

35. Glau CL, Conlon TW, Himebauch AS, Yehya N, Weiss SL, Berg RA, Nishisaki A : Progressive diaphragm atrophy in pediatric acute respiratory failure. Pediatr Crit Care Med $19: 406-411,2018$

36. Goligher EC : Myotrauma in mechanically ventilated patients. Intensive Care Med, 2019

37. Hershenson MB, Kikuchi Y, Tzelepis GE, McCool FD : Preferential fatigue of the rib cage muscles during inspiratory resistive loaded ventilation. J Appl Physiol (1985) 66 : 750754,1989

38. Capdevila X, Lopez S, Bernard N, Rabischong E, Ramonatxo M, Martinazzo G, Prefaut C : Effects of controlled mechanical ventilation on respiratory muscle contractile properties in rabbits. Intensive Care Med 29 : 103-110, 2003

39. Ju S, Lee SJ, Park MJ, Cho YJ, Jeong YY, Jeon KN, Bae K, Lee JD, Kim HC : Clinical importance of cross-sectional area of intercostal muscles in patients with chronic obstructive pulmonary disease. Clin Respir J 12 : 939-947, 2018

40. Files DC, Sanchez MA, Morris PE : A conceptual framework : the early and late phases of skeletal muscle dysfunction in the acute respiratory distress syndrome. Crit Care $19: 266,2015$

41. Witteveen E, Wieske L, van der Poll T, van der Schaaf M, van Schaik IN, Schultz MJ, Verhamme C, Horn J : Increased early systemic inflammation in ICU-acquired weakness ; a prospective observational cohort study. Crit Care Med 45 : 972-979, 2017

42. Puthucheary ZA, Astin R, McPhail MJW, Saeed S, Pasha Y, Bear DE, Constantin D, Velloso C, Manning S, Calvert 
L, Singer M, Batterham RL, Gomez-Romero M, Holmes E Steiner MC, Atherton PJ, Greenhaff P, Edwards LM, Smith K, Harridge SD, Hart N, Montgomery HE : Metabolic phenotype of skeletal muscle in early critical illness. Thorax $73:$ 926-935, 2018

43. Bonaldo P, Sandri M : Cellular and molecular mechanisms of muscle atrophy. Dis Model Mech 6 : 25-39, 2013

44. Taito S, Sanui M, Yasuda H, Shime N, Lefor AK : Current rehabilitation practices in intensive care units : a preliminary survey by the Japanese Society of Education for Physicians and Trainees in Intensive Care (JSEPTIC) Clinical Trial Group. J Intensive Care $4: 66,2016$

45. Schefold JC, Bierbrauer J, Weber-Carstens S : Intensive care unit-acquired weakness (ICUAW) and muscle wasting in critically ill patients with severe sepsis and septic shock. J Cachexia Sarcopenia Muscle 1: 147-157, 2010

46. Drummond MJ, Timmerman KL, Markofski MM, Walker DK, Dickinson JM, Jamaluddin M, Brasier AR, Rasmussen BB, Volpi E : Short-term bed rest increases TLR4 and IL-6 expression in skeletal muscle of older adults. Am J Physiol Regul Integr Comp Physiol 305 : R216-223, 2013

47. Klaude M, Mori M, Tjader I, Gustafsson T, Wernerman J, Rooyackers $\mathrm{O}$ : Protein metabolism and gene expression in skeletal muscle of critically ill patients with sepsis. Clin Sci $122: 133-142,2012$

48. Uozumi M, Sanui M, Komuro T, Iizuka Y, Kamio T, Koyama H, Mouri H, Masuyama T, Ono K, Lefor AK : Interruption of enteral nutrition in the intensive care unit : a single-center survey. J Intensive Care 5 : 52, 2017

49. Tatsumi H : Enteral tolerance in critically ill patients. J Intensive Care $7: 30,2019$

50. Vanhorebeek I, De Vos R, Mesotten D, Wouters PJ, De Wolf-Peeters C, Van den Berghe G : Protection of hepatocyte mitochondrial ultrastructure and function by strict blood glucose control with insulin in critically ill patients. Lancet $365: 53-59,2005$

51. Hirata Y, Nomura K, Senga Y, Okada Y, Kobayashi K, Okamoto S, Minokoshi Y, Imamura M, Takeda S, Hosooka $\mathrm{T}$, Ogawa $\mathrm{W}$ : Hyperglycemia induces skeletal muscle atrophy via a WWP1/KLF15 axis. JCI Insight 4, 2019

52. Nanas S, Kritikos K, Angelopoulos E, Siafaka A, Tsikriki S, Poriazi M, Kanaloupiti D, Kontogeorgi M, Pratikaki M, Zervakis D, Routsi C, Roussos C : Predisposing factors for critical illness polyneuromyopathy in a multidisciplinary intensive care unit. Acta Neurol Scand 118: 175-181, 2008

53. Yang T, Li Z, Jiang L, Wang Y, Xi X: Risk factors for intensive care unit-acquired weakness : a systematic review and meta-analysis. Acta Neurol Scand 138: 104-114, 2018

54. Yang T, Li Z, Jiang L, Xi X: Corticosteroid use and intensive care unit-acquired weakness : a systematic review and meta-analysis. Crit Care $22: 187,2018$

55. Wolfe KS, Patel BK, MacKenzie EL, Giovanni SP, Pohlman AS, Churpek MM, Hall JB, Kress JP : Impact of vasoactive medications on ICU-acquired weakness in mechanically ventilated patients. Chest 154 : 781-787, 2018

56. Leatherman JW, Fluegel WL, David WS, Davies SF, Iber $\mathrm{C}$ : Muscle weakness in mechanically ventilated patients with severe asthma. Am J Respir Crit Care Med 153 : 16861690, 1996

57. Burniston JG, Chester N, Clark WA, Tan LB, Goldspink $\mathrm{DF}$ : Dose-dependent apoptotic and necrotic myocyte death induced by the beta2-adrenergic receptor agonist, clenbuterol. Muscle Nerve 32 : 767-774, 2005

58. Goldspink DF, Burniston JG, Ellison GM, Clark WA, Tan LB : Catecholamine-induced apoptosis and necrosis in cardiac and skeletal myocytes of the rat in vivo: the same or separate death pathways? Exp Physiol 89 : 407-416, 2004

59. Grill MF, Maganti RK: Neurotoxic effects associated with antibiotic use : management considerations. Br J Clin Pharmacol $72: 381-393,2011$

60. Zambon M, Beccaria P, Matsuno J, Gemma M, Frati E, Colombo S, Cabrini L, Landoni G, Zangrillo A : Mechanical ventilation and diaphragmatic atrophy in critically ill patients : an ultrasound study. Crit Care Med 44 : 1347-1352, 2016

61. Marin-Corral J, Dot I, Boguna M, Cecchini L, Zapatero A, Gracia MP, Pascual-Guardia S, Vila C, Castellvi A, Perez-Teran P, Gea J, Masclans JR : Structural differences in the diaphragm of patients following controlled vs assisted and spontaneous mechanical ventilation. Intensive Care Med 45 : 488-500, 2019

62. Lindqvist J, van den Berg M, van der Pijl R, Hooijman PE, Beishuizen A, Elshof J, de Waard M, Girbes A, Spoelstra-de Man A, Shi ZH, van den Brom C, Bogaards S, Shen S, Strom J, Granzier H, Kole J, Musters RJP, Paul MA, Heunks LMA, Ottenheijm CAC : Positive end-expiratory pressure ventilation induces longitudinal atrophy in diaphragm fibers. Am J Respir Crit Care Med 198: 472-485, 2018

63. Goligher EC : Myotrauma in mechanically ventilated patients. Intensive Care Med $45: 881-884,2019$

64. Stevens RD, Marshall SA, Cornblath DR, Hoke A, Needham DM, de Jonghe B, Ali NA, Sharshar T : A framework for diagnosing and classifying intensive care unit-acquired weakness. Crit Care Med 37 : S299-308, 2009

65. De Jonghe B, Sharshar T, Lefaucheur JP, Authier FJ, Durand-Zaleski I, Boussarsar M, Cerf C, Renaud E, Mesrati F, Carlet J, Raphael JC, Outin H, Bastuji-Garin S : Paresis acquired in the intensive care unit : a prospective multicenter study. Jama 288 : 2859-2867, 2002

66. Muscedere J, Waters B, Varambally A, Bagshaw SM, Boyd JG, Maslove D, Sibley S, Rockwood K : The impact of frailty on intensive care unit outcomes : a systematic review and meta-analysis. Intensive Care Med 43 : 1105-1122, 2017

67. Palakshappa JA, Bakhru RN : Bedside ultrasonography can and should be used in the ICU to evaluate muscle atrophy. Ann Am Thorac Soc, 2019

68. Pardo E, El Behi H, Boizeau P, Verdonk F, Alberti C, Lescot $\mathrm{T}$ : Reliability of ultrasound measurements of quadriceps muscle thickness in critically ill patients. BMC Anesthesiol $18: 205,2018$

69. Zaidman CM, Wu JS, Wilder S, Darras BT, Rutkove $\mathrm{SB}$ : Minimal training is required to reliably perform quantitative ultrasound of muscle. Muscle Nerve $50: 124-128$, 2014

70. Bunnell A, Ney J, Gellhorn A, Hough CL : Quantitative neuromuscular ultrasound in intensive care unit-acquired weakness : a systematic review. Muscle Nerve 52 : 701-708, 2015

71. Puthucheary ZA, McNelly AS, Rawal J, Connolly B, Sidhu PS, Rowlerson A, Moxham J, Harridge SD, Hart N, Montgomery HE : Rectus femoris cross-sectional area and muscle layer thickness : comparative markers of muscle wasting and weakness. Am J Respir Crit Care Med $195: 136-138,2017$

72. Palakshappa JA, Reilly JP, Schweickert WD, Anderson BJ, Khoury V, Shashaty MG, Fitzgerald D, Forker C, Butler K, Ittner CA, Feng R, Files DC, Bonk MP, Christie JD, Meyer NJ : Quantitative peripheral muscle ultrasound in sepsis : muscle area superior to thickness. J Crit Care $47: 324$ 330,2018

73. Cartwright MS, Kwayisi G, Griffin LP, Sarwal A, Walker 
FO, Harris JM, Berry MJ, Chahal PS, Morris PE : Quantitative neuromuscular ultrasound in the intensive care unit. Muscle Nerve $47: 255-259,2013$

74. Campbell IT, Watt T, Withers D, England R, Sukumar S, Keegan MA, Faragher B, Martin DF : Muscle thickness, measured with ultrasound, may be an indicator of lean tissue wasting in multiple organ failure in the presence of edema. Am J Clin Nutr 62 : 533-539, 1995

75. Zambon M, Greco M, Bocchino S, Cabrini L, Beccaria PF, Zangrillo A : Assessment of diaphragmatic dysfunction in the critically ill patient with ultrasound: a systematic review. Intensive Care Med 43 : 29-38, 2017

76. Pillen S, Tak RO, Zwarts MJ, Lammens MM, Verrijp KN, Arts IM, van der Laak JA, Hoogerbrugge PM, van Engelen BG, Verrips A : Skeletal muscle ultrasound : correlation between fibrous tissue and echo intensity. Ultrasound Med Biol 35 : 443-446, 2009

77. Kim D, Sun JS, Lee YH, Lee JH, Hong J, Lee JM : Comparative assessment of skeletal muscle mass using computerized tomography and bioelectrical impedance analysis in critically ill patients. Clin Nutr, 2018

78. Malbrain ML, Huygh J, Dabrowski W, De Waele JJ, Staelens A, Wauters $\mathrm{J}$ : The use of bio-electrical impedance analysis (BIA) to guide fluid management, resuscitation and deresuscitation in critically ill patients : a bench-to-bedside review. Anaesthesiol Intensive Ther 46 : 381-391, 2014

79. Looijaard W, Molinger J, Weijs PJM : Measuring and monitoring lean body mass in critical illness. Curr Opin Crit Care 24 : 241-247, 2018

80. Bloch SA, Lee JY, Wort SJ, Polkey MI, Kemp PR, Griffiths $\mathrm{MJ}$ : Sustained elevation of circulating growth and differentiation factor-15 and a dynamic imbalance in mediators of muscle homeostasis are associated with the development of acute muscle wasting following cardiac surgery. Crit Care Med 41: 982-989, 2013

81. Bloch SA, Lee JY, Syburra T, Rosendahl U, Griffiths MJ, Kemp PR, Polkey MI : Increased expression of GDF-15 may mediate ICU-acquired weakness by down-regulating muscle microRNAs. Thorax 70 : 219-228, 2015

82. Kashani KB, Frazee EN, Kukralova L, Sarvottam K, Herasevich V, Young PM, Kashyap R, Lieske JC : Evaluating muscle mass by using markers of kidney function : development of the sarcopenia index. Crit Care Med 45 : e23-e29, 2017

83. Oterdoom LH, Gansevoort RT, Schouten JP, de Jong PE, Gans RO, Bakker SJ : Urinary creatinine excretion, an indirect measure of muscle mass, is an independent predictor of cardiovascular disease and mortality in the general population. Atherosclerosis $207: 534-540,2009$

84. Iida Y, Yamazaki T, Kawabe T, Usui A, Yamada S : Postoperative muscle proteolysis affects systemic muscle weakness in patients undergoing cardiac surgery. Int $\mathrm{J}$ Cardiol 172 : 595-597, 2014

85. Schweickert WD, Pohlman MC, Pohlman AS, Nigos C, Pawlik AJ, Esbrook CL, Spears L, Miller M, Franczyk M, Deprizio D, Schmidt GA, Bowman A, Barr R, McCallister KE, Hall JB, Kress JP : Early physical and occupational therapy in mechanically ventilated, critically ill patients : a randomised controlled trial. Lancet $373:$ 1874-1882, 2009

86. Calvo-Ayala E, Khan BA, Farber MO, Ely EW, Boustani MA : Interventions to improve the physical function of ICU survivors : a systematic review. Chest 144 : 1469-1480, 2013

87. Patel BK, Pohlman AS, Hall JB, Kress JP : Impact of early mobilization on glycemic control and ICU-acquired weakness in critically ill patients who are mechanically ventilated. Chest $146: 583-589,2014$
88. Vorona S, Sabatini U, Al-Maqbali S, Bertoni M, Dres M, Bissett B, Van Haren F, Martin AD, Urrea C, Brace D, Parotto M, Herridge MS, Adhikari NKJ, Fan E, Melo LT, Reid WD, Brochard LJ, Ferguson ND, Goligher EC : Inspiratory muscle rehabilitation in critically ill adults. a systematic review and meta-analysis. Ann Am Thorac Soc $15: 735-744,2018$

89. Iwatsu K, Yamada S, Iida Y, Sampei H, Kobayashi K, Kainuma M, Usui A : Feasibility of neuromuscular electrical stimulation immediately after cardiovascular surgery. Arch Phys Med Rehabil 96 : 63-68, 2015

90. Gerovasili V, Stefanidis K, Vitzilaios K, Karatzanos E, Politis P, Koroneos A, Chatzimichail A, Routsi C, Roussos $\mathrm{C}$, Nanas S : Electrical muscle stimulation preserves the muscle mass of critically ill patients : a randomized study. Crit Care $13:$ R161, 2009

91. Fossat G, Baudin F, Courtes L, Bobet S, Dupont A, Bretagnol A, Benzekri-Lefevre D, Kamel T, Muller G, Bercault N, Barbier F, Runge I, Nay MA, Skarzynski M, Mathonnet A, Boulain T : Effect of in-bed leg cycling and electrical stimulation of the quadriceps on global muscle strength in critically ill adults : a randomized clinical trial. Jama 320 : 368-378, 2018

92. Gruther W, Kainberger F, Fialka-Moser V, Paternostro-Sluga T, Quittan M, Spiss C, Crevenna R : Effects of neuromuscular electrical stimulation on muscle layer thickness of knee extensor muscles in intensive care unit patients : a pilot study. J Rehabil Med 42 : 593-597, 2010

93. Rodriguez PO, Setten M, Maskin LP, Bonelli I, Vidomlansky SR, Attie S, Frosiani SL, Kozima S, Valentini R : Muscle weakness in septic patients requiring mechanical ventilation : protective effect of transcutaneous neuromuscular electrical stimulation. J Crit Care 27 : 319.e311-318, 2012

94. Nishida O, Ogura H, Egi M, Fujishima S, Hayashi Y, Iba T, Imaizumi H, Inoue S, Kakihana Y, Kotani J, Kushimoto S, Masuda Y, Matsuda N, Matsushima A, Nakada TA, Nakagawa S, Nunomiya S, Sadahiro T, Shime N, Yatabe T, Hara Y, Hayashida K, Kondo Y, Sumi Y, Yasuda H, Aoyama K, Azuhata T, Doi K, Doi M, Fujimura N, Fuke R, Fukuda T, Goto K, Hasegawa R, Hashimoto S, Hatakeyama J, Hayakawa M, Hifumi T, Higashibeppu N, Hirai K, Hirose T, Ide K, Kaizuka Y, Kan'o T, Kawasaki T, Kuroda H, Matsuda A, Matsumoto S, Nagae M, Onodera M, Ohnuma T, Oshima K, Saito N, Sakamoto S, Sakuraya M, Sasano M, Sato N, Sawamura A, Shimizu K, Shirai K, Takei T, Takeuchi M, Takimoto K, Taniguchi T, Tatsumi H, Tsuruta R, Yama N, Yamakawa K, Yamashita C, Yamashita K, Yoshida T, Tanaka H, Oda S : The Japanese clinical practice guidelines for management of sepsis and septic shock 2016 (J-SSCG 2016). Acute Med Surg 5 : 3-89, 2018

95. Sommers J, Engelbert RH, Dettling-Ihnenfeldt D, Gosselink R, Spronk PE, Nollet F, van der Schaaf M : Physiotherapy in the intensive care unit : an evidence-based, expert driven, practical statement and rehabilitation recommendations. Clin Rehabil 29 : 1051-1063, 2015

96. Reynolds SC, Meyyappan R, Thakkar V, Tran BD, Nolette MA, Sadarangani G, Sandoval RA, Bruulsema L, Hannigan B, Li JW, Rohrs E, Zurba J, Hoffer JA : Mitigation of ventilator-induced diaphragm atrophy by transvenous phrenic nerve stimulation. Am J Respir Crit Care Med 195 : 339348, 2017

97. Evans D, Shure D, Clark L, Criner GJ, Dres M, de Abreu MG, Laghi F, McDonagh D, Petrof B, Nelson T, Similowski $\mathrm{T}$ : Temporary transvenous diaphragm pacing vs. standard of care for weaning from mechanical ventilation : study protocol for a randomized trial. Trials $20: 60,2019$ 
98. Dres M, Goligher EC, Heunks LMA, Brochard LJ : Critical illness-associated diaphragm weakness. Intensive Care Med 43: 1441-1452, 2017

99. Yoshida T, Torsani V, Gomes S, De Santis RR, Beraldo MA, Costa EL, Tucci MR, Zin WA, Kavanagh BP, Amato MB : Spontaneous effort causes occult pendelluft during mechanical ventilation. Am J Respir Crit Care Med 188 : 14201427,2013

100. Umbrello M, Formenti P, Longhi D, Galimberti A, Piva I, Pezzi A, Mistraletti G, Marini JJ, Iapichino G : Diaphragm ultrasound as indicator of respiratory effort in critically ill patients undergoing assisted mechanical ventilation : a pilot clinical study. Crit Care 19: 161, 2015

101. Needham DM, Dinglas VD, Morris PE, Jackson JC, Hough CL, Mendez-Tellez PA, Wozniak AW, Colantuoni E, Ely EW, Rice TW, Hopkins RO : Physical and cognitive performance of patients with acute lung injury 1 year after initial trophic versus full enteral feeding. EDEN trial follow-up. Am J Respir Crit Care Med 188 : 567-576, 2013

102. Casaer MP, Langouche L, Coudyzer W, Vanbeckevoort D, De Dobbelaer B, Guiza FG, Wouters PJ, Mesotten D, Van den Berghe G : Impact of early parenteral nutrition on muscle and adipose tissue compartments during critical illness. Crit Care Med $41: 2298-2309,2013$

103. Hermans G, Casaer MP, Clerckx B, Guiza F, Vanhullebusch T, Derde S, Meersseman P, Derese I, Mesotten D, Wouters PJ, Van Cromphaut S, Debaveye Y, Gosselink R, Gunst J, Wilmer A, Van den Berghe G, Vanhorebeek I : Effect of tolerating macronutrient deficit on the development of intensive-care unit acquired weakness : a subanalysis of the EPaNIC trial. Lancet Respir Med $1: 621-629,2013$

104. Bohe J, Low JF, Wolfe RR, Rennie MJ : Latency and duration of stimulation of human muscle protein synthesis during continuous infusion of amino acids. J Physiol $532: 575-579,2001$

105. Gunst J, Vanhorebeek I, Casaer MP, Hermans G, Wouters PJ, Dubois J, Claes K, Schetz M, Van den Berghe G : Impact of early parenteral nutrition on metabolism and kidney injury. J Am Soc Nephrol 24 : 995-1005, 2013

106. Marino PL, Millili JJ : Possible role of dietary lipids in critical illness polyneuropathy. Intensive Care Med 24 : 87, 1998

107. McClave SA, Taylor BE, Martindale RG, Warren MM, Johnson DR, Braunschweig C, McCarthy MS, Davanos E, Rice TW, Cresci GA, Gervasio JM, Sacks GS, Roberts
PR, Compher C : Guidelines for the povision and assessment of nutrition support therapy in the adult critically ill patient : Society of Critical Care Medicine (SCCM) and American Society for Parenteral and Enteral Nutrition (A.S.P.E.N.). JPEN J Parenter Enteral Nutr 40 : 159-211, 2016

108. Singer P, Blaser AR, Berger MM, Alhazzani W, Calder PC, Casaer MP, Hiesmayr M, Mayer K, Montejo JC, Pichard C, Preiser JC, van Zanten ARH, Oczkowski S, Szczeklik W, Bischoff SC : ESPEN guideline on clinical nutrition in the intensive care unit. Clin Nutr 38 : 48-79, 2019

109. Allingstrup MJ, Kondrup J, Wiis J, Claudius C, Pedersen UG, Hein-Rasmussen R, Bjerregaard MR, Steensen M, Jensen TH, Lange T, Madsen MB, Moller MH, Perner A : Early goal-directed nutrition versus standard of care in adult intensive care patients : the single-centre, randomised, outcome assessor-blinded EAT-ICU trial. Intensive Care Med 43 : 1637-1647, 2017

110. Derde S, Vanhorebeek I, Guiza F, Derese I, Gunst J, Fahrenkrog B, Martinet W, Vervenne H, Ververs EJ, Larsson L, Van den Berghe G : Early parenteral nutrition evokes a phenotype of autophagy deficiency in liver and skeletal muscle of critically ill rabbits. Endocrinology $153: 2267-2276$, 2012

111. Ferrie S, Allman-Farinelli M, Daley M, Smith K: Protein requirements in the critically ill : a randomized controlled trial using parenteral nutrition. JPEN J Parenter Enteral Nutr $40: 795-805,2016$

112. Yatabe T, Egi M, Sakaguchi M, Ito T, Inagaki N, Kato H, Kaminohara J, Konishi A, Takahashi M, Tatsumi H, Tobe M, Nakashima I, Nakamoto N, Nishimura T, Nitta M, Nishimura M : Influence of nutritional management and rehabilitation on physical outcome in Japanese intensive care unit patients : a multicenter observational study. Ann Nutr Metab 74: 35-43, 2019

113. Hermans G, Wilmer A, Meersseman W, Milants I, Wouters PJ, Bobbaers H, Bruyninckx F, Van den Berghe G : Impact of intensive insulin therapy on neuromuscular complications and ventilator dependency in the medical intensive care unit. Am J Respir Crit Care Med 175 : 480-489, 2007

114. Ferrando AA, Chinkes DL, Wolf SE, Matin S, Herndon DN, Wolfe RR : A submaximal dose of insulin promotes net skeletal muscle protein synthesis in patients with severe burns. Ann Surg 229 : 11-18, 1999 